\title{
Study of Soluble Lipoprotein in Rat Liver Mitochondria
}

\author{
By S. V. KOPPIKAR,* P. FATTERPAKER AND A. SREENIVASAN \\ Biochemistry and Food Technology Division, Bhabha Atomic Research Centre, Bombay 85, India
}

(Received 16 June 1970)

\begin{abstract}
1. A water-soluble lipoprotein was isolated and purified from osmotically shocked preparations of rat liver mitochondria by using a technique of Sephadex-sandwich disc electrophoresis. 2. The purified lipoprotein migrates as a distinct sharp zone in high-resolution electrophoretic systems, indicating high degree of purity. 3. The liproprotein resembles mitochondrial membranes with respect to lipid composition and lipid/protein ratio. 4. The lipoprotein and its apoprotein fraction obtained by delipidization at $-18^{\circ} \mathrm{C}$ to $-20^{\circ} \mathrm{C}$ have common properties with respect to their fluorescence spectra, instability to storage and electrophoretic mobility. 5. The purified lipoprotein has an excitation maximum at $325 \mathrm{~nm}$ and a fluorescence maximum at $418 \mathrm{~nm}$. 6. Storage at $4^{\circ} \mathrm{C}$ for 4 days or repeated freezing and thawing results in $\mathbf{1 5 - 3 0 \%}$ decrease in electrophoretic mobility. 7. The patterns of incorporation in vitro of $\left[1-{ }^{14} \mathrm{C}\right]$ leucine into proteins of the soluble lipoprotein and of mitochondrial membrane of isolated rat liver mitochondria suggest a probable precursor role for the apoprotein in the formation of mitochondrial membrane protein. 8. Lipoprotein preparations isolated from mitochondrial fractions of rat kidney, brain and heart and of chicken and mouse liver resemble closely that obtained from rat liver mitochondria, suggesting that the soluble lipoprotein could be a distinct entity of mitochondrial origin.
\end{abstract}

Cellular lipoproteins can be classified into two groups: (i) insoluble lipoproteins of cellular and subcellular membranes; (ii) soluble lipoproteins such as those present in the intracellular fluid spaces of the cell cytoplasm. Bhargava \& Sreenivasan (1966, 1968) have reported the presence of soluble lipoproteins in rat liver cell cytoplasm. The occurrence of soluble lipoprotein in rat liver nuclei is known (Levvi \& Thomas, 1963; Wang, Mayer \& Thomas, 1953). Although membrane lipoproteins have been extensively studied in recent years, scant attention has been paid to the existence of soluble lipoproteins in membrane-bounded cellular structures. A few reports about soluble lipoproteins from mitochondria are available (Assuita \& Dianzani, 1959; de Lamirande, Allard \& Cantero, 1953; Ugazio, 1960). However, the drastic conditions followed in these studies, involving the use of detergents and ultrasonic disintegration, make it impossible to distinguish between the truly soluble and the solubilized lipoproteins. The present work describes the isolation, purification and some characteristics of a truly soluble lipoprotein released from mitochondria after osmotic-shock treatment.

* Present address: Department of Biochemistry, University of Sheffield, Sheffield S10 2TL, U.K.

\section{MATERIALS}

D- $\beta$-Hydroxybutyrate, L-malate, $\mathrm{NADH}, \mathrm{NAD}^{+}, \mathrm{ADP}$, tris and oxaloacetate were purchased from Sigma Chemical Co., St Louis, Mo., U.S.A. Acrylamide and $N N N^{\prime} N^{\prime}-$ tetramethylethylenediamine were purchased from KochLight Laboratories Ltd., Colnbrook, Bucks., U.K. Sephadex was purchased from Pharmacia A.B., Uppsala, Sweden. 2,4-Dinitrophenol and CTP were purchased from Nutritional Biochemicals Corp., Cleveland, Ohio, U.S.A. DL- $\left[1-{ }^{14} \mathrm{C}\right]$ Leucine $(45.8 \mathrm{mCi} / \mathrm{mmol})$ was obtained from Isotope Division, Bhabha Atomic Research Centre, Trombay, Bombay, India. $\left[\mathrm{Me}^{14} \mathrm{C}\right]$ Choline chloride (41.6 $\mathrm{mCi} / \mathrm{mmol})$ was purchased from The Radiochemical Centre, Amersham, Bucks., U.K. All other chemicals used were either BDH Chemicals Ltd. (Poole, Dorset, U.K.) AnalaR grade or E. Merck A.-G. (Darmstadt, Germany) Pro Analyst quality.

\section{METHODS}

Preparation of mitochondria. Normal Wistar-strain male rats maintained on standard laboratory stock diet and of body weight 150-175 g were killed by decapitation. Livers were quickly removed and placed in chilled $0.25 \mathrm{M}$ sucrose $\left(4^{\circ} \mathrm{C}\right)$. A $10 \%(\mathrm{w} / \mathrm{v})$ liver homogenate in $0.25 \mathrm{M}$ sucrose solution was prepared in a Potter-Elvehjem-type glass homogenizer (Arthur H. Thomas Co., Philadelphia, Pa., U.S.A.) with a Teflon pestle. The nuclear fraction and cell debris were sedimented at $650 \mathrm{~g}$ for $10 \mathrm{~min}$ and 
discarded. The nuclei-free homogenate was centrifuged at $6500 \mathrm{~g}$ for $10 \mathrm{~min}$ to sediment the heavy-mitochondrial fraction (International Equipment Co. PR-2, Multispeed rotor no. 855). The loosely packed fluffy layer was sloughed off completely by layering small amounts of sucrose solution. The heavy-mitochondrial pellet was then washed four times by repeated suspension in $0.25 \mathrm{M}$ sucrose and resedimentation at $6500 \mathrm{~g}$ for $10 \mathrm{~min}$ to minimize adhering cytoplasmic contamination. All operations were carried out at $0-4^{\circ} \mathrm{C}$. Mitochondria from heart and brain were isolated by the procedures of Smith (1967) and Lovtrup \& Zelander (1962) respectively. Kidney mitochondria were prepared from the cortex after removal of the medullary portion, by the procedure followed for rat liver.

Osmotic-shock treatment. Isolated mitochondria were suspended in ice-cold water at a protein concentration of $1-2.5 \mathrm{mg} / \mathrm{ml}$ and maintained at $4^{\circ} \mathrm{C}$. At regular intervals the membrane fraction was sedimented at $105000 \mathrm{~g}$ for $1 \mathrm{~h}$ in a Beckman L-2-65 ultracentrifuge. The clear supernatant so obtained was termed the soluble phase. Mitochondrial soluble phase was concentrated by single-step continuous freeze-drying or by using reverse dialysis against polyethylene glycol 6000 at $4^{\circ} \mathrm{C}$. Such concentrates were used in all further studies. Efficiency of osmotic shock in releasing mitochondrial soluble contents was assessed by measuring the proteins and the lipids in the soluble phase at different time-intervals.

Determination of protein and lipid. Proteins were determined by the method of Lowry, Rosebrough, Farr \& Randall (1951). Lipids were extracted from mitochondrial fractions with chloroform-methanol $(2: 1, \mathrm{v} / \mathrm{v})$ as described by Folch, Lees \& Sloane-Stanley (1957). For all lipid determinations pipetted samples were freed of the solvent by evaporation under $\mathrm{N}_{2}$. Total lipids were determined by the dichromate method of Bragdon (1950). Total cholesterol was determined by the method of Zlatkis, Zak \& Boyle (1953). Glycerides were determined as described by Van Handel \& Zilversmit (1957). Phospholipids were determined after digestion with $\mathrm{H}_{2} \mathrm{SO}_{4}$ in terms of $P_{1}$ by the method of Bartlett (1959).

Tests for membrane contamination. D- $\beta$-Hydroxybutyrate dehydrogenase activity was measured by the method of Lehninger, Sudduth \& Wise (1960). The reaction mixture in the spectrophotometer cuvette contained tris- $\mathrm{HCl}$ buffer, pH8.5 (40 m $)$, NaCN (10 m M), sodium DL- $\beta$-hydroxybutyrate (10 mM), $\mathrm{NAD}^{+}(1 \mathrm{~mm})$ and an adequate amount of protein from mitochondrial fractions. The reaction was started by the addition of $\mathrm{NAD}^{+}$and the increase in $E_{340}$ was measured at $15 \mathrm{~s}$ intervals.

The presence of structural protein was semi-quantitatively assessed by solubilization of mitochondrial fractions with sodium dodecyl sulphate and its subsequent precipitation at $12 \%$ saturation with $\left(\mathrm{NH}_{4}\right)_{2} \mathrm{SO}_{4}$ (Criddle, Bock, Green \& Tisdale, 1962). The final volume of the system was $3 \mathrm{ml}$. Formation of precipitate was followed by turbidimetric assay at $540 \mathrm{~nm}$ in a Beckman DU spectrophotometer.

Column chromatography. Sephadex G-200 was allowed

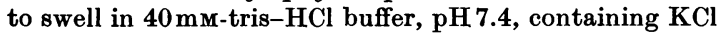
$(40 \mathrm{~mm})$. The swollen gel was uniformly packed in a column $(1.6 \mathrm{~cm}$ diam. $\times 50 \mathrm{~cm}$ high). A sample of mitochondrial soluble phase containing $120 \mathrm{mg}$ of protein was loaded on to the gel column and was eluted at a flow rate of $8 \mathrm{ml} / \mathrm{h}$ with the above-mentioned tris-HCl buffer. Fractions of volume $2.5 \mathrm{ml}$ were collected and protein and lipid were determined.

Electrophoretic systems. At various stages of lipoprotein purification polyacrylamide disc electrophoresis was used to assess the degree of purification. For this system the acrylamide concentration of the small-pore running gel was lowered to $5.25 \%$. The spacer gel was also modified to contain $0.05 \%$ of bisacrylamide and $2.5 \%$ of acrylamide, which was chemically polymerized with potassium persulphate at a final concentration of $0.07 \%(w / v)$. The sample gel was not used; instead the sample equilibrated with spacer-gel buffer containing $10 \%(\mathrm{w} / \mathrm{v})$ of sucrose was loaded on to the system followed by a short layer of spacer-gel buffer containing $5 \%(w / v)$ of sucrose, to minimize diffusion losses of the sample into the upper buffer reservoir. All other details of the system were essentially as described by Davis (1964).

For the Sephadex-sandwich disc electrophoresis system a layer of Sephadex G-200 equilibrated with a suitable buffer containing $10 \%(\mathrm{w} / \mathrm{v})$ of sucrose was sandwiched between two layers (columns) of polyacrylamide gels (Koppikar, Fatterpaker \& Sreenivasan, 1970). Other details of the system were identical with the polyacrylamide disc-electrophoretic system mentioned above, except that an ungelled sucrose space $3-4 \mathrm{~mm}$ thick was left in the lower gel. The distance of this sucrose space from the bottom of the gel tube was kept constant at $1 \mathrm{~cm}$. Glass tubes of 6-15 mm diam. can be employed for the formation of this system.

Electrophoresis was performed at a constant current of $5 \mathrm{~mA} /$ tube and continued until the lipoprotein band had migrated through Sephadex and running polyacrylamide gels into the ungelled sucrose space. Elcctrophoresis was then stopped and the gel plugs were removed after inversion of the tubes. The lipoprotein that had collected in the sucrose space was poured into a suitable container, with a single rinsing of the sucrose space to ensure maximum recovery. For analytical runs the sucrose space was omitted from the lower gel and electrophoresis was stopped when the liproprotein band had migrated to about $1-1.5 \mathrm{~cm}$ near the lower end; gels were then removed and suitably stained.

Staining. Pre-staining of the lipoprotein was carried out with Sudan Black B in ethylene glycol as described by McDonald \& Ribiro (1959). Amido Black was used as a protein stain (Davis, 1964).

Isolation of apoprotein. The soluble lipoprotein was delipidized with ethanol-ether $(1: 3, \mathrm{v} / \mathrm{v})$ at $-18^{\circ} \mathrm{C}$ to $-20^{\circ} \mathrm{C}$ in glass-stoppered tubes. The protein precipitate was centrifuged and washed repeatedly with chilled ether to remove any residual ethanol and dried under vacuum. All these operations were carried out at $-18^{\circ} \mathrm{C}$ to $-20^{\circ} \mathrm{C}$.

Fluorescence measurements. Excitation and fluorescence spectra of lipoprotein and apoprotein samples were carried out in an Aminco-Bowman spectrophotofluorimeter and were recorded with the help of Mosely $\mathrm{X}-\mathrm{Y}$ recorder. Measurement of relative intensities were performed at fixed wavelengths without the use of slits. For determination of excitation and fluorescence maxima, the band width was limited by the use of a $0.2 \mathrm{~mm}$ slit on the excitation and fluorescence sides respectively.

Storage and electrophoretic mobility. Lipoprotein 
and apoprotein samples were stored in ground-glassstoppered tubes under $\mathrm{N}_{2}$ at $4^{\circ} \mathrm{C}$, or alternatively were stored frozen and thawed just before measurement of electrophoretic mobility in polyacrylamide gels. The distance traversed by the protein front in $5 \mathrm{~min}$ was measured optically by using a travelling microscope (National Instrument Corp., Ambala Cant, India). Mobility was calculated and expressed in terms of mobility units, each unit being equivalent to $1 \times 10^{-5} \mathrm{~cm}$ per $\mathrm{s} / \mathrm{V}$ per $\mathrm{cm}$.

Incorporation in vitro of $\left[1-{ }^{14} \mathrm{C}\right]$ leucine by isolated mitochondria. The synthetic amino acid mixture was prepared as described by Roodyn, Reis \& Work (1961). The final incorporation medium was prepared as described by Beattie, Basford \& Koritz (1967a), and contained sodium succinate (10 mM), ATP or ADP (2 mM), EDTA (2 mM), tris-HCl buffer, pH $7.2(50 \mathrm{~mm})$, sodium phosphate buffer, pH 7.2 (20 mM), $\mathrm{MgCl}_{2}(5 \mathrm{mM})$, complete amino acid mixture $(45 \mu \mathrm{g} / \mathrm{ml})$ and $0.5 \mu \mathrm{Ci}$ of $\mathrm{DL}-\left[1-{ }^{14} \mathrm{C}\right]$ leucine/ $\mathrm{ml}$ of the medium. The reaction was started by the addition of 2-3 $\mathrm{mg}$ of mitochondrial protein $/ \mathrm{ml}$ of medium. Incubations were carried out at $30^{\circ} \mathrm{C}$ in $25 \mathrm{ml}$ conical flasks containing $6 \mathrm{ml}$ of incorporation medium, with continuous shaking in $\mathrm{O}_{2}$ atmosphere. At intervals of 0 , $10,20,30,45$ and $60 \mathrm{~min}$ the incorporation of radioactivity was terminated by the addition of a large excess ( 50 times the amount of label used) of pre-chilled unlabelled leucine in $0.25 \mathrm{M}$-sucrose solution and immediate centrifugation at $6500 \mathrm{~g}$ for $10 \mathrm{~min}$. The mitochondrial pellets so obtained were twice suspended in $0.25 \mathrm{M}$-sucrose containing unlabelled leucine and resedimented at $6500 \mathrm{~g}$ for $10 \mathrm{~min}$ to remove all traces of extraneous radioactivity. Osmoticshock treatment of mitochondria and isolation and purification of the soluble lipoprotein were performed as described above. The insoluble residue after removal of the soluble phase was designated the membrane fraction.

Effect of inhibitors. Effective inhibitors of mitochondrial protein synthesis, namely chloramphenicol (1 $\mathrm{mM})$, 2,4-dinitrophenol (0.5 mM) and $\mathrm{KCN}$ (1 $\mathrm{mM})$, were added separately to the incubation mixture before the addition of mitochondria. For incubation under anaerobic conditions $\mathrm{N}_{2}$ was bubbled through the medium for $10 \mathrm{~min}$; mitochondrial suspension was then added and the flasks were stoppered. The effect of these inhibitors on amino acid incorporation was studied at 10 and $30 \mathrm{~min}$ of incubation. Termination of reaction, washing of mitochondria and isolation of purified lipoprotein were performed as described above.

Incorporation in vitro of $\left[\mathrm{Me}^{-14} \mathrm{C}\right]$ choline by isolated mitochondria. The incorporation medium was prepared as described by Kaiser \& Bygrave (1968), and included $\mathrm{KCl}(100 \mathrm{~mm})$, potassium succinate (1 $\mathrm{mm}), \mathrm{MgCl}_{2}(5 \mathrm{~mm})$, potassium phosphate buffer, $\mathrm{pH} 7.3(20 \mathrm{mM})$, and $0.5 \mu \mathrm{Ci}$ of $\left[M e-{ }^{14} \mathrm{C}\right] \mathrm{choline}$ chloride/ml of medium. Incubation conditions were same as for the amino acid-incorporation system, except that $5 \mathrm{ml}$ of final volume and $32^{\circ} \mathrm{C}$ were employed. At the end of $5,10,20,30,40,50$ and $60 \mathrm{~min}$ the incorporation of radioactivity was terminated by the addition of a large excess (50 times the amount of label used) of pre-chilled unlabelled choline chloride in $0.25 \mathrm{M}$ sucrose solution. Post-incubation sedimentation and washing of mitochondria, osmotic shock treatment and isolation of purified lipoprotein were carried out exactly as described for the amino acid-incorporation studies.
Measurement of radioactivity. Radioactivity was counted in a Packard Tri-Carb model 314 EX liquidscintillation spectrometer with the scintillator system described by Bray (1960). The counting efficiency for ${ }^{14} \mathrm{C}$ was $60 \%$. Specific radioactivities of different mitochondrial fractions are expressed as c.p.m./mg of protein.

\section{RESULTS}

Isolation of a soluble lipoprotein from mitochondria. Rat liver mitochondria, obtained by repeated suspension in $0.25 \mathrm{M}$-sucrose and sedimentation at $6500 \mathrm{~g}$ for $10 \mathrm{~min}$ to minimize cytoplasmic contamination, were given osmotic shock to release their soluble contents. The optimum time for osmotic shock, judged by examination of the release of soluble proteins and lipids at different time-intervals, was found to be $1 \mathrm{~h}$ (Figs. 1 and 2).

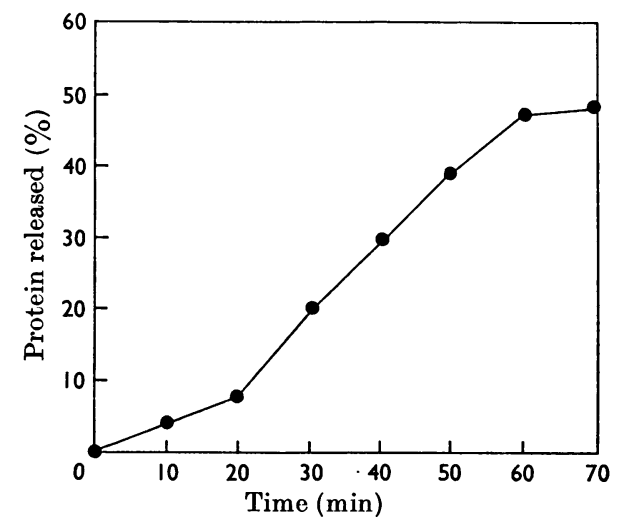

Fig. 1. Release of mitochondrial proteins during osmotic shock. Mitochondria were suspended in ice-cold water at a concentration of $1-2.5 \mathrm{mg} / \mathrm{ml}$. At intervals the membrane fraction was sedimented at $105000 \mathrm{~g}$ for $1 \mathrm{~h}$. Protein was determined in the supernatant fraction and recorded as percentage of the total mitochondrial protein. Details are given in the text.

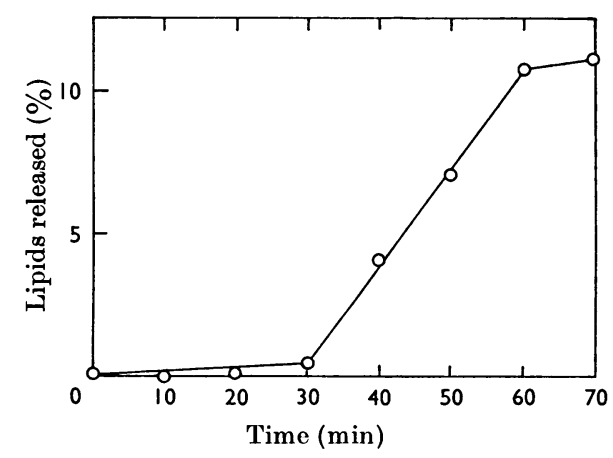

Fig. 2. Release of mitochondrial lipids during osmotic shock. Details are given in Fig. 1 legend and in the text. 


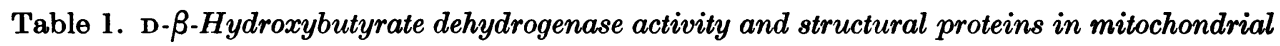
fractions

The determinations of enzyme activity and the structural protein were carried out as described in the text. The percentage of the enzyme was calculated on the basis of the protein content of the membrane fraction, which represents $55 \%$ of mitochondrial total proteins. For the determination of structural proteins the concentrations of mitochondrial and mitochondrial-membrane protein were in the range 100-250 $\mu \mathrm{g}$, whereas the concentration of soluble phase used was $5-10 \mathrm{mg}$ per assay in a total volume of $3 \mathrm{ml}$. The results given are typical of four sets of independent experiments.

\section{D- $\beta$-Hydroxybutyrate dehydrogenase activity}

\section{Fractions}

Whole mitochondria

Mitochondrial-membrane fraction

Mitochondrial soluble phase

\section{$\left(\Delta E_{340} / \mathrm{min}\right.$ per}

$\mathrm{mg}$ of protein)

0.215

0.368

Nil

(\% recovery)
100
95

Nil

Structural
proteins
$\left(\Delta E_{540} / \mathrm{mg}\right.$ of
protein)
1.82
3.46
Nil

Structural

$\left(\Delta E_{540} / \mathrm{mg}\right.$ of rotein)

$\mathrm{Nil}$

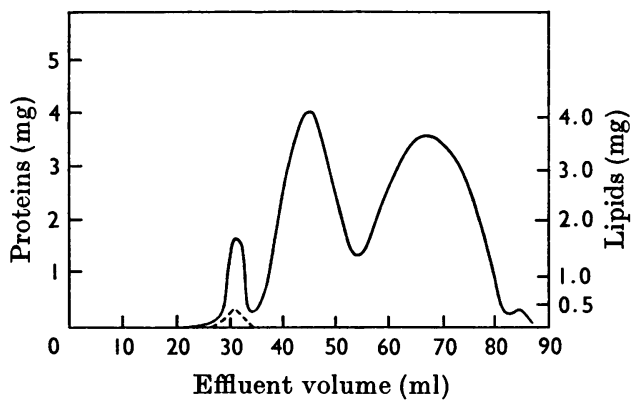

Fig. 3. Column chromatography of mitochondrial soluble phase. Mitochondrial soluble phase was chromatographed on Sephadex G-200 gel with $40 \mathrm{~mm}$-tris-HCl buffer, $\mathrm{pH} 7.4$, containing $\mathrm{KCl}(40 \mathrm{~mm})$ as eluent, at a flow rate of $8 \mathrm{ml} / \mathrm{h}$. The total load applied was $120 \mathrm{mg}$. Ordinate units represent $\mathrm{mg}$ of protein (-) or lipid $(---)$ per fraction $(2.5 \mathrm{ml})$. Other details are given in the text.

During this time $45-48 \%$ of the total proteins and $10 \%$ of the total lipids were released in the soluble phase, there being no further release thereafter. It was observed that the lipids consisted largely of phospholipids (90\%). Cholesterol, free fatty acids and neutral glycerides were only $5.1,3.1$ and $2.8 \%$ respectively. A study of $\mathbf{D}-\beta$-hydroxybutyrate dehydrogenase and of structural proteins (Table 1) indicated the absence of these constituents from the soluble phase, thereby excluding membrane contamination.

When a sample of the concentrated soluble phase was submitted to gel filtration through a column of Sephadex G-200, a single zone emerging in the void volume gave reactions for both lipids and proteins, indicating the presence of a lipid-protein complex (Fig. 3). This lipid-protein complex

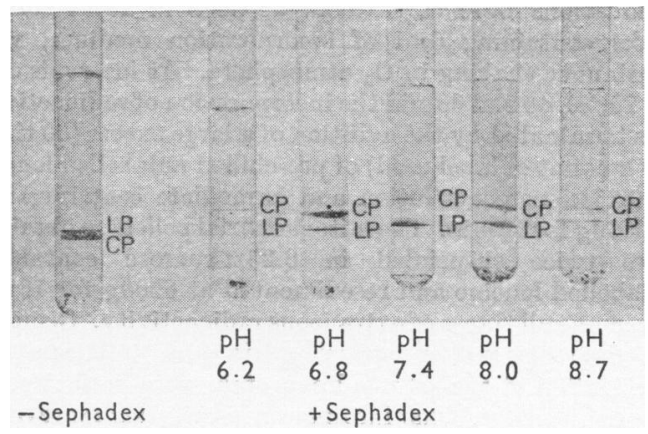

Fig. 4. Separation of mitochondrial soluble lipoprotein (LP) from contaminant protein (CP) as a function of the pH of the Sephadex-gel buffer. Tris-HCl buffer was prepared by keeping the $\mathrm{Cl}^{-}$ion concentration the same as in the polyacrylamide-gel buffers, but the $\mathrm{pH}$ was varied by the addition of tris. For $\mathrm{pH} 6.2$ and $\mathrm{pH} 6.8$ phosphate buffer of the same molarity was used to which KCl was added to maintain the $\mathrm{Cl}^{-}$ion concentration constant. All buffers used for Sephadex-gel equilibration contained $10 \%(w / v)$ of sucrose. Other details are given in the text.

migrated as a sharp single band when subjected to electrophoresis on $5.25 \%$ polyacrylamide gel. The band was stainable with both lipid and protein stains. Though most of the contaminating proteins were removed by Sephadex chromatography, a protein contaminant migrating close to the complex was evident on disc electrophoresis (Fig. 4).

Purification of the lipoprotein by Sephadexsandwich disc electrophoresis. Removal of the protein contaminant was possible on a Sephadex G-50 column. However, successive chromatographic steps resulted in dilution of the sample, necessitating repeated concentration, and were time-consuming. This processing delay resulted in 
degradation of the unstable lipoprotein. To obviate this and to obtain a speedy and effective single-step purification, a modification of gel electrophoresis, namely Sephadex-sandwich diso electrophoresis, was devised. This system is fully discussed elsewhere (Koppikar, Fatterpaker \& Sreenivasan, 1970). Fig. 4 shows the effect of varying the $\mathrm{pH}$ of the Sephadex-gel buffer on the resolution of the lipoprotein. Maximum separation could be effected at pH 7.4, since the Sephadex column effectively retarded the contaminating protein. Migration of the purified lipoprotein as a single sharp zone on re-electrophoresis in polyacrylamide and Sephadexsandwich disc electrophoresis indicated a high degree of purity (Fig. 5). The final yield of the purified lipoprotein was about $2 \%$ of the mitochondrial protein.

Lipid composition of the lipoprotein. The total lipid content of the lipoprotein, purified as above, averaged $276 \pm 16.7 \mu \mathrm{g} / \mathrm{mg}$ of protein in five independent determinations. Phospholipids and sterols constituted $91 \%$ and $5 \%$ respectively of the total lipids. The lipid/protein ratio was $1: 3.5$ (w/w). In these respects therefore the composition of the soluble lipoprotein corresponded closely to that of mitochondrial membrane (Parsons, 1967).

Fluorescence spectra. Fluorescence characteristics

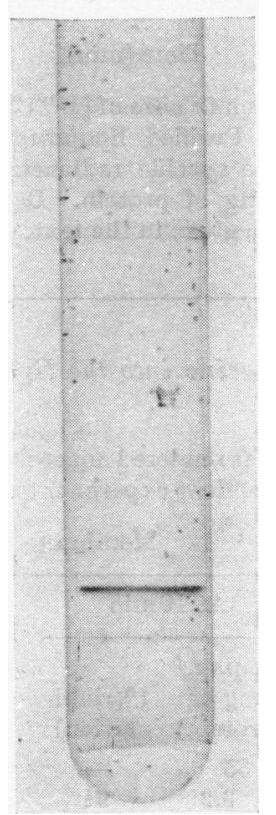

Fig. 5. Purified lipoprotein on Sephadex-sandwich and polyacrylamide-gel disc electrophoresis. Gel dimensions were $8 \mathrm{~mm}$ diam. $\times 5 \mathrm{~cm}$ long; the direction of flow was downward. Other details are given in the text. of the lipoprotein and the apoprotein were found to be identical and unique. Unlike those for other soluble proteins, the excitation maximum was observed at $325 \mathrm{~nm}$ and the fluorescence maximum at $418 \mathrm{~nm}$ (Fig. 6). Degradation of protein struoture of mitochondrial lipoprotein by acid dodecyl sulphate $(2.5 \%$ sodium dodecyl sulphate in $0.5 \mathrm{M}$ hydrochloric acid) gave a fluorescence maximum at $345 \mathrm{~nm}$ (Fig. 7).

Electrophoretic mobility. The apoprotein of the soluble lipoprotein migrated as a sharp single zone in high-resolution dise-electrophoretic systems. Its electrophoretic mobility is identical with that of the parent lipoprotein. This indicated that the lipid moiety of the lipoprotein oontributes no net charge to the complex. This was further confirmed by the fact that pre-staining of the lipid moiety did not alter the electrophoretic mobility of the lipoprotein (Table 5).

Measurement of mobility by direct optical observations during polyacrylaminde-gel electrophoresis was possible since the protein moiety of the lipoprotein had a faint yellow (straw) colour.

The electrophoretic mobility of the lipoprotein and the apoprotein from rat liver was altered after 2 days of storage at $4^{\circ} \mathrm{C}$, and on the fourth day it had decreased by about $30-35 \%$ of its original value. Successive freezing and thawing more than three times also brought about a $10 \%$ decrease in the electrophoretic mobility.

To ascertain whether the lipoprotein is synthesized by the mitochondria its labelling by $\left[1-{ }^{14} \mathrm{C}\right]$ leucine and $\left[\mathrm{Me}^{-14} \mathrm{C}\right]$ choline during active incorporation of these components in vitro by isolated

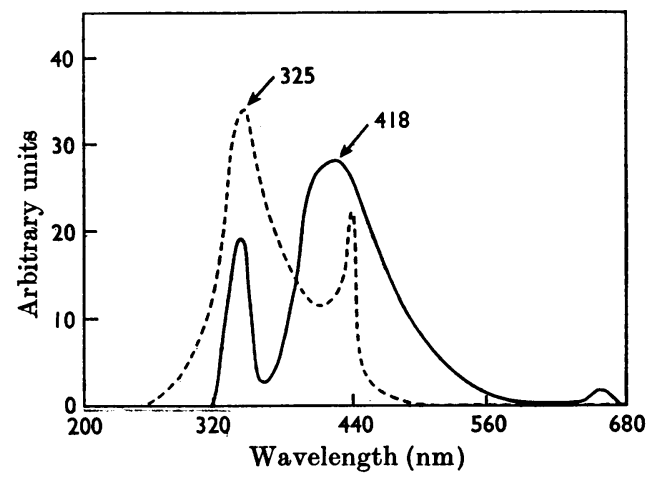

Fig. 6. Fluorescence and excitation spectra of purified lipoprotein and apoprotein. - Fluorescence spectrum at excitation maximum $325 \mathrm{~nm}$; ----, excitation spectrum; fluorescence measurements were taken at $440 \mathrm{~nm}$. Purified soluble lipoprotein and the apoprotein obtained from it were taken up in 0.1 M-phosphate buffer, pH 7.4. Fluorescence and excitation spectra were recorded in an Aminco-Bowman spectrophotofluorimeter. 
mitochondria was studied. Simultaneous labelling of mitochondrial membrane was also followed for comparison.

Incorporation in vitro of $\left[1-{ }^{14} \mathrm{C}\right]$ leucine by isolated mitochondria. It was observed (Table 2) that potassium cyanide, 2,4-dinitrophenol, chloramphenicol and anaerobiosis all inhibited the incorporation of the labelled amino acid into the soluble lipoprotein and the membrane fraction by isolated mitochondria. The extent of inhibition was 86$94 \%$ compared with normal values. Incubation at $4^{\circ} \mathrm{C}$ or without shaking decreased the incorporation by $80-82 \%$ in the lipoprotein and by $72-79 \%$ in the membrane fraction. These studies indicated a true incorporation in vitro of amino acids into the

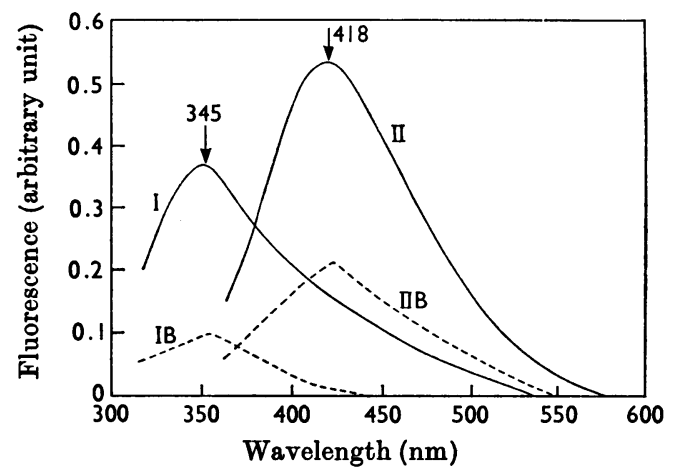

Fig. 7. Fluorescence spectra of degraded lipoprotein. Curve I, lipoprotein in $0.5 \mathrm{M}-\mathrm{HCl}$ containing $2.5 \%(\mathrm{w} / \mathrm{v})$ of sodium dodecyl sulphate, excitation maximum $265 \mathrm{~nm}$; curve IB, blank. Curve II, lipoprotein in $0.1 \mathrm{M}$ phosphate buffer, excitation maximum $325 \mathrm{~nm}$; curve IIB, blank. The lipoprotein concentration was $2 \mathrm{mg} / \mathrm{ml}$. soluble lipoprotein and the membrane fraction of isolated mitochondria.

The time-course of incorporation in vitro of $\left[1-{ }^{14} \mathrm{C}\right]$ leucine into the mitochondrial soluble lipoprotein and the membrane fraction is presented in Fig. 8. The lipoprotein became rapidly labelled within the first $10 \mathrm{~min}$, after which its specific radioactivity declined steadily up to $60 \mathrm{~min}$. In contrast,

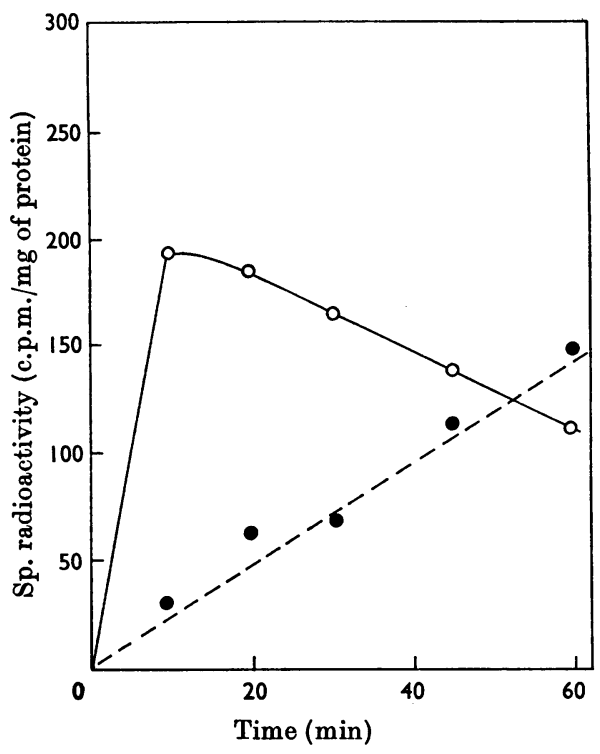

Fig. 8. Incorporation in vitro of $\left[1-{ }^{14} \mathrm{C}\right]$ leucine by isolated mitochondria. $\bigcirc$, Purified lipoprotein; $\bullet$, membrane fraction. Zero-time specific radioactivities were in the range 6-8 c.p.m./mg of protein. Details of the incorporation system are given in the text.

Table 2. Effect of inhibitors on incorporation in vitro of $\left[1-{ }^{14} \mathrm{C}\right]$ leucine into the lipoprotein and the membrane fraction

Experimental details are described in the text. The incubation medium was rendered anaerobic by bubbling $\mathrm{N}_{2}$ through it for $10 \mathrm{~min}$. The results given are typical of four sets of independent experiments.

Lipoprotein

$\overbrace{\begin{array}{c}\text { (c.p.m. } / \\ \text { mg of }(\% \text { inhi- }\end{array}}^{\text {At } 10 \mathrm{~min}} \overbrace{\begin{array}{c}\text { (c.p.m. } / \\ \text { mg of }(\% \text { inhi- }\end{array}(\%)}^{\text {At } 30 \mathrm{~min}}$

\section{Temp.}

Addition

None

2,4-Dinitrophenol

(0.5 m M)

$\mathrm{KCN}(1 \mathrm{mM})$

Anaerobic medium

Chloramphenicol (1 mM)

None $\left({ }^{\circ} \mathrm{C}\right)$ protein) bition) protein) bition)

$\begin{array}{rrrr}190 & - & 135 & - \\ 11.4 & 94 & 9.5 & 93 \\ & & & \\ 15.2 & 92 & 13.3 & 90 \\ 20.9 & 89 & 12.2 & 91 \\ 22.8 & 88 & 17.5 & 87 \\ 34.2 & 82 & 27.0 & 80\end{array}$

Membrane fraction

$\overbrace{\begin{array}{c}\text { (c.p.m. }) \\ \text { mg of }(\% \text { inhi- }\end{array}}^{\text {At } 10 \text { min }} \overbrace{\left.\begin{array}{c}\text { (c.p.m. }) \\ \text { mg of }(\% \text { inhi- }\end{array}\right)}^{\text {At } 30 \text { min }}$

protein) bition) protein) bition)

$\begin{array}{clrl}35 & & 70 & - \\ 3.2 & 91 & 8.4 & 88 \\ 3.4 & 90 & 9.0 & 87 \\ 3.7 & 89.5 & 9.8 & 86 \\ 3.6 & 89 & 14.0 & 80 \\ 7.3 & 79 & 19.4 & 72\end{array}$


Table 3. Distribution of radioactivity in mitochondrial fractions during incorporation in vitro of $\left[1-{ }^{14} \mathrm{C}\right]$ leucine by isolated mitochondria

Details of the incorporation system, isolation of fractions and measurement of radioactivity are given in the text. The specific radioactivities of whole mitochondria measured at 10,30 and 60 min were 20,36 and 73 c.p.m./mg of protein respectively. The results are means \pm s.e.M. of four sets of experiments.

$\begin{array}{ccccc}\text { Incubation } & \begin{array}{c}\text { \% of } \\ \text { period } \\ (\mathrm{min})\end{array} & \begin{array}{c}\text { Ritochondrial } \\ \text { proteins }\end{array} & \begin{array}{c}\text { (c.p.m./mg of } \\ \text { protein) }\end{array} & \text { (\% of total) } \\ \text { Muritochondrial fraction } & 10 & 1.5 & 185 \pm 6 & 12.5 \\ \text { Membrane fraction } & 30 & 1.4 & 160 \pm 8 & 5.2 \\ & 60 & 1.2 & 115 \pm 5 & 1.6 \\ & 10 & 54.2 & 35 \pm 3 & 85.0 \\ & 30 & 52.6 & 68 \pm 5 & 94.0\end{array}$

there was a steady increase in the specific radioactivity of the membrane fraction during the same period.

At $10 \mathrm{~min}$ after the onset of amino acid incorporation by isolated mitochondria, the purified lipoprotein accounted for $12.5 \%$ of the total incorporated radioactivity (Table 3 ). This proportion decreased with time and at the end of $60 \mathrm{~min}$ the purified soluble lipoprotein accounted for only $1.6 \%$ of the total radioactivity. At the early interval of $10 \mathrm{~min}$ the soluble lipoprotein had a specific radioactivity significantly higher than that of the membrane fraction. It was also observed that the radioactivity present in the mitochondrial soluble phase was almost entirely due to the presence of the water-soluble lipoprotein.

The possibility of bacterial contamination can be a serious problem in such studies. This possibility in the present studies is, however, ruled out, because the observed time-course of incorporation was linear and not exponential as would be expected if bacteria were contributing towards incorporation. In addition, the differential labelling of the mitochondrial soluble lipoprotein and the membrane fraction (Table 3) argue in favour of a true mitochondrial protein synthesis, since in the case of bacterial incorporation of amino acids both soluble and insoluble protein fractions would be labelled to the same extent. Further, bacterial cell walls cannot be ruptured by osmotic shock alone. This and the extensive purification of the lipoprotein before measurement of radioactivity makes it unlikely that there was any significant contribution from bacterial sources.

Incorporation of $\left[M e-{ }^{14} \mathrm{C}\right]$ choline into mitochondrial phospholipids. During incorporation in vitro of $\left[M e^{-14} \mathrm{C}\right]$ choline (Fig. 9) the specific radioactivity of the soluble lipoprotein reached a peak value at $20 \mathrm{~min}$, after which it declined up to $60 \mathrm{~min}$.

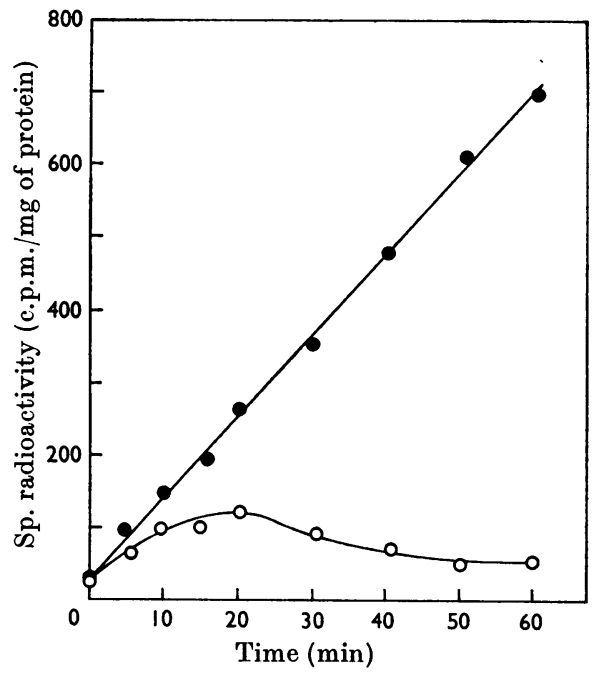

Fig. 9. Incorporation in vitro of $\left[M e^{-14} \mathrm{C}\right]$ choline by isolated mitochondria. $O$, Purified lipoprotein; $\bullet$, membrane fraction. Since radioactivity was not detected in lipid-free mitochondrial fractions, the specific radioactivities are expressed in terms of c.p.m./mg of protein. Details of the incorporation system are given in the text.

The specific radioactivity of the membrane fraction increased steadily during the same period.

At all stages of incorporation in vitro of choline (Fig. 9 and Table 4) the soluble lipoprotein had a lower specific radioactivity than that of the mitochondrial-membrane fraction. The soluble lipoprotein, even at its peak specific radioactivity, accounted for only $3.3 \%$ of the total incorporated radioactivity, and this value further declined with time to a negligibly low value at $60 \mathrm{~min}$.

Organ and species specificity. A lipoprotein 
Table 4. Distribution of radioactivity in mitochondrial fractions during incorporation in vitro of $\left[\mathrm{Me}-{ }^{14} \mathrm{C}\right]$ choline by isolated mitochondria

Details of the incorporation system, isolation of fractions and measurement of radioactivity counting are given in the text. The specific radioactivities of whole mitochondria measured at 10, 20, 40 and 60 min were $74,129,238$ and 360 c.p.m./mg of protein respectively. The results are means \pm S.e.M. of four sets of experiments.

\begin{tabular}{|c|c|c|c|c|}
\hline \multirow[b]{2}{*}{ Mitochondrial fraction } & \multirow[b]{2}{*}{$\begin{array}{c}\text { Incubation } \\
\text { period } \\
(\mathrm{min})\end{array}$} & \multirow[b]{2}{*}{$\begin{array}{c}\% \text { of } \\
\text { mitochondrial } \\
\text { proteins }\end{array}$} & \multicolumn{2}{|c|}{ Radioactivity } \\
\hline & & & $\begin{array}{l}\text { (c.p.m./mg of } \\
\text { protein) }\end{array}$ & ( $\%$ of total) \\
\hline Purified soluble lipoprotein & $\begin{array}{l}10 \\
20 \\
40 \\
60\end{array}$ & $\begin{array}{l}1.8 \\
1.5 \\
1.4 \\
1.1\end{array}$ & $\begin{array}{r}95 \pm 5 \\
122 \pm 7 \\
70 \pm 3 \\
50 \pm 5\end{array}$ & \begin{tabular}{l|l|}
3.3 \\
2.4 \\
0.85 \\
0.2
\end{tabular} \\
\hline Membrane fraction & $\begin{array}{l}10 \\
20 \\
40 \\
60\end{array}$ & $\begin{array}{l}53.2 \\
51.8 \\
52.4 \\
50.6\end{array}$ & $\begin{array}{l}145 \pm 10 \\
255 \pm 29 \\
476 \pm 28 \\
710 \pm 40\end{array}$ & $\begin{array}{l}96.0 \\
97.3 \\
98.1 \\
98.9\end{array}$ \\
\hline
\end{tabular}

Table 5. Electrophoretic mobility of mitochondrial lipoprotein and apoprotein

Mobility determination and conditions of storage were as given in the text. The results given are typical of six independent determinations. $10^{-5} \times$ Electrophoretic mobility $(\mathrm{cm}$ per $\mathrm{s} / \mathrm{V}$ per $\mathrm{cm})$

\begin{tabular}{|c|c|c|c|c|c|c|}
\hline \multirow{2}{*}{$\begin{array}{c}\text { Sample } \\
\text { Source of sample }\end{array}$} & \\
\hline & ... Rat liver & Rat brain & Rat kidney & Rat heart & Chicken liver & Mouse liver \\
\hline Lipoprotein & 5.096 & 5.024 & 5.788 & 4.902 & 5.124 & 5.407 \\
\hline Apoprotein & 5.052 & 5.067 & 5.763 & 5.010 & 5.092 & 5.361 \\
\hline $\begin{array}{l}\text { Lipoprotein stored } \\
\text { for } 4 \text { days at } 4^{\circ} \mathrm{C}\end{array}$ & 3.380 & 3.138 & 3.406 & $\mathbf{3 . 3 8 0}$ & - & - \\
\hline Lipoprotein frozen & 4.580 & 4.598 & 4.930 & 4.428 & - & - \\
\hline
\end{tabular}

and thawed three

times

fraction similar to that obtained from rat liver mitochondria could also be obtained from rat kidney, brain and heart and from chicken and mouse liver, by following the procedures adopted for rat liver mitochondria. These lipoproteins had identical fluorescence characteristics. The fluorescence intensities, messured in terms of arbitrary units ( $\%$ transmission $\times$ sensitivity setting), were 0.944 (rat liver), 0.915 (rat kidney), 0.937 (rat brain), 0.923 (rat heart), 0.916 (chicken liver) and 0.968 (mouse liver), all expressed per mg of protein. They resembled each other closely in lipid composition and lipid/protein ratio. Their electrophoretic mobilities and stability towards storage and freezethawing were also similar (Table 5). Thus a considerable decrease in the electrophoretio mobilities of these lipoproteins and their apoproteins was observed after storage for 2 days at $4^{\circ} \mathrm{C}$ and after successive freeze-thawing. The lipoprotein and the apoprotein from rat kidney mitochondria tended to migrate slightly faster than did the others. A decrease in electrophoretic mobility on storage and freeze-thawing cyoles can be attributed to the aggregation that probably occurs during storage, leading to eventual precipitation.

\section{DISCUSSION}

When mitochondria were subjected to osmotic shock, a small but consistent amount of lipids (10\%) with a considerable amount of proteins (45-48\%) were released in the soluble phase (Figs. 1 and 2). The rather slow initial release of proteins and lipids after osmotic shock could perhaps be explained on the basis of the present information on compartmentation in mitochondria (Klingenberg \& Pfaff, 1966; Packer, 1970a,b), according to which the matrix represents an organized series of compartments differing in binding and association of macromolecules. The lag of $30 \mathrm{~min}$ in the release of lipids could be also due to differential permeability of mitochondrial membranes towards proteins and lipoproteins during osmotic shock.

The composition and the peroentage of released 
lipids agreed fairly well with the results reported by Bartley, Getz, Notton \& Renshaw (1962) except for the neutral lipids, the reported values being higher than those obtained in the present investigation. We attribute this to a difference in the method of preparation of mitochondria, since it has been observed that repeated suspension in $0.25 \mathrm{~m}$-sucrose and resedimentation of the mitochondrial fraction removes the loosely adhering cytoplasm, comparatively rich in neutral lipids, to a considerable extent. After four such washings of mitochondria the quality and quantity of lipids released do not change with further washings (S. V. Koppikar, P. Fatterpaker \& A. Sreenivasan, unpublished work). It was observed that part of these lipids could be co-precipitated with proteins by the addition of $10 \%(\mathrm{w} / \mathrm{v})$ trichloroacetic acid (S. V. Koppikar, P. Fatterpaker \& A. Sreenivasan, unpublished work), a fact that suggested a probable occurrence of soluble lipoprotein(s) in mitochondria. These observations were further substantiated by columnchromatographic and gel-electrophoresis studies (Figs. 3 and 4).

The possibility of this lipoprotein arising out of either cytoplasmic contamination or as a breakdown product of mitochondrial membranes seems to be ruled out for the following reasons. (1) The extent of cytoplasmic contamination was minimized by giving repeated washings to mitochondrial fractions. In separate experiments it was ascertained that the microsomal and lysosomal contaminations in such mitochondrial preparations, as judged by their respective marker enzymes, glucose 6-phosphatase and acid phosphatase, were 1.2 and $1.9 \%$ respectively. (2) The method of osmotic shock adopted to release the soluble contents is the mildest known. Even during $60 \mathrm{~min}$ duration of shock extensive subfragmentation of mitochondrial membranes is highly improbable, since the osmotic pressure acting on the membranes during the fully distended state would decrease considerably once the mitochondrial membranes had ruptured at some place, thus preventing further breakage. (3) Solubilization of mitochondrial membrane components by lysosomal cathepsins and/or phospholipases (Mellors \& Tappel, 1967) also seems unlikely in view of low incidences of lysosomal contamination. The presence of endogenous proteases (Alberti \& Bartley, 1963, 1965) and phospholipases (Rossi, Sartorelli, Tato, Baretta \& Siliprandi, 1965; Scherphof \& van Deenen, 1965) in mitochondria have been shown. However, for optimum protease activity the minimum mitochondrial protein concentration has to be about $5 \mathrm{mg} / \mathrm{ml}$ of reaction mixture (M. Subramanian, P. Fatterpaker \& A. Sreenivasan, unpublished work). Also, the phospholipase activity in mitochondria is generally so low that, even with 6-10 mg of mitochondrial protein $/ \mathrm{ml}$ of incubation medium, radioactive lipids have to be used for the detection of enzyme activity (Waite \& van Deenen, 1967). In the present study the possibility of the involvement of these enzymes in the breakdown of membrane components is further decreased by the use of a low temperature $\left(4^{\circ} \mathrm{C}\right)$ and by the dilution of the mitochondrial susfension, and consequently of these enzymes contained therein, during osmotic shock. (4) Centrifugation of the mitochondrial suspension after osmotic shock at $105000 \mathrm{~g}$ for $1 \mathrm{~h}$ ensures the complete removal of all probable membrane fragments from the soluble phase, as has also been shown by a complete absence of the membrane markers, D- $\beta$-hydroxybutyrate dehydrogenase and structural proteins, from the soluble phase (Table 1).

The lipoprotein and its apoprotein exhibited unusual characteristics with regard to fluorescence and excitation maxima, which were found to be at $418 \mathrm{~nm}$ and at $325 \mathrm{~nm}$ respectively (Fig. 6). Konev (1967) has discussed the contribution of different amino acids to protein fluorescence. In proteins containing tryptophan this amino acid masks the fluorescence due to all other amino acids, including phenylalanine and tyrosine, so that only the tryptophan maximum appears in the fluorescence spectrum (Teale, 1960; Vladimirov \& Burshtein, 1960). The variation observed in the fluorescence maxima of the proteins containing tryptophan ranges from $328 \mathrm{~nm}$ for edestin to $342 \mathrm{~nm}$ of bovine serum albumin. It was observed that degradation of protein structure of mitochondrial lipoprotein by acid dodecyl sulphate $(2.5 \%$ sodium dodecyl sulphate in $0.5 \mathrm{~m}$-hydrochloric acid) resulted in partial restoration of the tryptophan fluorescence spectrum (Fig. 7). It therefore appears probable that all the fluorescent groups native to proteins, i.e. tryptophan, tyrosine and phenylalanine, are either masked in this lipoprotein or that their characteristics are modified to a large extent. A possibility also exists that non-protein components (NADH and/or pyridoxamine) that may be present in the lipoprotein could contribute to the unusual fluorescence spectrum; in such a case, the appearance of tryptophan fluorescence in presence of sodium dodecyl sulphate could be explained as due to dissociation of the cofactor(s). However, further work will be necessary to rule out these possibilities.

The purified lipoprotein resembled mitochondrial membranes in respect of its lipid composition and lipid/protein ratio. The results of the incorporation in vitro of $\left[1-{ }^{14} \mathrm{C}\right]$ leucine into the soluble lipoprotein and mitochondrial membrane indicated that there was an initial rapid labelling of the lipoprotein followed by a subsequent decrease, with a concomitant increase in the specific radioactivity in the membrane fraction, implying a precursor-product relationship. The pattern of the incorporation of 


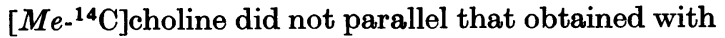
$\left[1-{ }^{14} \mathrm{C}\right]$ leucine. At all stages of choline incorporation the specific radioactivity in the lipoprotein was never higher than that of the membrane fraction and there was a time lag in reaching peak specific radioactivity. This could be explained if we assume that the formation of a soluble apoprotein precedes the synthesis of a lipoprotein. Such conclusions, however, should await further studies in which labelling of lipid and protein moieties of the lipoprotein are measured simultaneously at optimum rates; it should be borne in mind that the synthetic activities of isolated mitochondria with labelled leucine and choline as precursors, observed in the present study, are not strictly comparable, since the conditions under which the two systems were studied are distinctly different. The present observations on choline incorporation therefore appear to be difficult to explain at the present time. However, the data on the incorporation of leucine indicate a possibility that the apoprotein of the soluble lipoprotein may act as a precursor of some of the membrane proteins. Further work is needed to confirm this assumption. There are a few reports to indicate that the membrane systems of the cell can be rapidly reformed when localized gentle disturbances are induced in the membrane structure (Chambers \& Chambers, 1961; Heilbrun, 1956; Dawson, 1966). Such instant formation of membranes in situ suggests that soluble precursors exist in equilibrium with the membrane structures.

The fact that soluble lipoproteins having identical properties with respect to fluorescence characteristics, lipid composition and stability towards stress as reflected by changes in electrophoretic mobilities are obtainable from mitochondria of rat kidney, brain and heart, as well as of chicken and mouse liver, also argue for the presence of the soluble lipoprotein being an independent entity, of mitochondrial origin, with a probable specific function.

The present studies are of significance in view of the existing information on the genesis of mitochondria. It has been suggested that the membrane lipoproteins are synthesized by the mitochondria themselves (Roodyn, 1962; Beattie, Basford \& Koritz, 1967b; Neupert, Brdiczka \& Bucher, 1967) and that the respiratory enzymes, cytochromes and other components synthesized on endoplasmic reticulum may be transferred to this lipoprotein skeleton (Freeman, Haldar \& Work, 1967; Kadenbach, 1967 ; Beattie, Basford \& Koritz, 1966; González-Cadavid \& Campbell, 1967), resulting in completion of mitochondrial formation. Also of relevance is the observation by Katyare, Fatterpaker \& Sreenivasan (1970) that differential centrifugation of mitochondrial suspensions could produce particulate material probably representing transitional forms leading to mature heavy mitochondria.
Presence of promitochondria in anaerobically grown Saccharomyces cerevisiae has been demonstrated by Criddle \& Schatz (1969) and lends additional support to this probable mode of mitochondrial biogenesis.

\section{REFERENCES}

Alberti, K. G. M. M. \& Bartley, W. (1963). Biochem. J. 87, 104.

Alberti, K. G. M. M. \& Bartley, W. (1965). Biochem. J. 95, 641 .

Assuita, M. \& Dianzani, M. (1959). Experientia, 15, 461.

Bartlett, G. R. (1959). J. biol. Chem. 234, 466.

Bartley, W., Getz, G. S., Notton, B. M. \& Renshaw, A. (1962). Biochem. J. 82, 540.

Beattie, D. S., Basford, R. E. \& Koritz, S. B. (1966). Biochemistry, Easton, 5, 926.

Beattie, D. S., Basford, R. E. \& Koritz, S. B. (1967a). J. biol. Chem. $242,3366$.

Beattie, D. S., Basford, R. E. \& Koritz, S. B. (1967b). Biochemistry, Easton, 6, 3099.

Bhargava, M. M. \& Sreenivasan, A. (1966). Biochem. J. $100,647$.

Bhargava, M. M. \& Sreenivasan, A. (1968). Indian J. Biochem. 5, 77.

Bragdon, H. H. (1950). J. biol. Chem. 190, 513.

Bray, G. A. (1960). Analyt. Biochem. 1, 279.

Chambers, R. \& Chambers, E. L. (1961). In Explorations into the Nature of the Living Cell, p. 100. Cambridge, Mass.: Harvard University Press.

Criddle, R. S., Bock, R. M., Green, D. E. \& Tisdale, H. D. (1962). Biochemistry, Easton, 1, 827.

Criddle, R. S. \& Schatz, G. (1969). Biochemistry, Easton, 8, 322.

Davis, B. J. (1964). Ann. N.Y. Acad. Sci. 121, 404.

Dawson, R. M. C. (1966). In Essays in Biochemistry, vol. 2, p. 69. Ed. by Campbell, P. N. \& Greville, G. D. London and New York: Academic Press.

de Lamirande, G., Allard, C. \& Cantero, A. (1953). Cancer, N.Y., 6, 179.

Folch, J., Lees, M. M. \& Sloane-Stanley, G. H. (1957). J. biol. Chem. 226, 497.

Freeman, K. B., Haldar, D. \& Work, T. S. (1967). Biochem. J. 105, 947.

González-Cadavid, N. F. \& Campbell, P. N. (1967). Biochem. J. 105, 443.

Heilbrun, L. V. (1956). In The Dynamics of Living Protoplasm, p. 64. New York: Academic Press Inc.

Kadenbach, B. (1967). Biochim. biophys. Acta, 134, 430.

Kaiser, W. \& Bygrave, F. L. (1968). Eur. J. Biochem. 4, 582 .

Katyare, S. S., Fatterpaker, P. \& Sreenivasan, A. (1970). Biochem. J. 118, 111.

Klingenberg, M. \& Pfaff, E. (1966). In Biochim. biophys. Acta Library Vol. 7: Regulation of Metabolic Processes in Mitochondria, p. 180. Ed. by Tager, J. M., Papa, S., Quagliariello, E. \& Slater, E. C. Amsterdam: Elsevier Publishing Co.

Konev, S. V. (1967). Fluorescence and Phosphorescence of Proteins and Nucleic Acids, p. 9. Translated by Udenfriend, S. New York: Plenum Press.

Koppikar, S. V., Fatterpaker, P. \& Sreenivasan, A. (1970). Analyt. Biochem. 33, 366. 
Lehninger, A. L., Sudduth, H. C. \& Wise, J. B. (1960). J. biol. Chem. 235, 2450.

Levvi, E. \& Thomas, L. E. (1963). Expl Cell Res. 23, 363.

Lovtrup, S. \& Zelander, T. (1962). Expl Cell Res. 27, 468. Lowry, O. H., Rosebrough, N. J., Farr, A. L. \& Randall, R. J. (1951). J. biol. Chem. 193, 265.

McDonald, H. J. \& Ribiro, L. P. (1959). Clinica chim. Acta, 4, 458.

Mellors, A. \& Tappel, A. L. (1967). J. Lipid Res. 8, 479.

Neupert, W., Brdiczka, D. \& Bucher, T. (1967). Biochem. biophys. Res. Commun. 27, 488.

Packer, L. (1970a). Biochim. biophys. Acta, 205, 125.

Packer, L. (1970b). Biochim. biophys. Acta, 205, 135.

Parsons, D. F. (1967). Proc. Canadian Research Conference, p. 193. Oxford: Pergamon Press Ltd.

Roodyn, D. B. (1962). Biochem. J. 85, 177.

Roodyn, D. B., Reis, P. J. \& Work, T. S. (1961). Biochem. $J .80,9$.
Rossi, G. R., Sartorelli, L., Tato, L., Baretta, L. \& Siliprandi, N. (1965). Biochim. biophys. Acta, 98, 207.

Scherphof, G. L. \& van Deenen, L. L. M. (1965). Biochim. biophys. Acta, 98, 204.

Smith, A. L. (1967). In Methods in Enzymology, vol. 10, p. 82. Ed. by Estabrook, R. W. \& Pullman, M. E. New York: Academic Press Inc.

Teale, F. W. J. (1960). Biochem. J. 76, 381.

Ugazio, G. (1960). Experientia, 16, 349.

Van Handel, E. \& Zilversmit, D. B. (1957). J. Lab. clin. Med. 50, 152.

Vladimirov, Yu. A. \& Burshtein, E. A. (1960). Biofizika, $5,385$.

Waite, M. \& van Deenen, L. L. M. (1967). Biochim. biophys. Acta, 137, 498.

Wang, T. Y., Mayer, D. T. \& Thomas, L. E. (1953). Expl Cell Res. 4, 102.

Zlatkis, A., Zak, B. \& Boyle, A. J. (1953). J. Lab. clin. Med. 41, 486. 